\title{
Carta de Nascimento do Jus Civile.
}

\author{
Geraldo de Ulhoa Cintra \\ Professor assistente da Cadeira de Judiciário \\ Civil, livre-docente de Direito Romano na \\ Faculdade de Direito da U.S.P.
}

Uma teoria clássica admite que, com os reis expulsos de Roma, foi proclamada a República em 509 A.C. e criados dois magistrados supremos, pretores ou cônsules.

Teríamos assim uma transformação política de imporlância restrita, porque a organização geral continuaria a mesma. A novidade seria tão só a criação da magistratura colegiada e anual e acessòriamente leiga ${ }^{1}$.

Contrapondo-se a essa maneira clássica de versar o assunto, ilustres romanistas sustentam que a mudança foi muito mais profunda do que geralmente se pensa.

Comparando as noções radicalmente opostas de Regnum e de Res Publica, pensam que não se deu uma simples modificação de formas jurídico-políticas, mas que se elaborou, sôbre princípios outros, uma concepção absolutamente nova e imediata de poder ${ }^{2}$.

1.É a opinião de MOMMSEN e de Grard. Autores mais recentes, que seguem a doutrina dos dois grandes mestres, retificam a idéia da revolução de 509, tirando-lhe os foros de epopéia e lembrando sobretudo a revolta dos Latinos contra a opressão etrusca. A mudança do regime será acessória e tanto quanto fôsse reação política anti-etrusca.

2. E o pensamento de ColLI, no seu estudo Regnum, in Studia et Documenta Historiae et Juris, 1951, acompanhado por DE FraNCIScI, Dal Regnum alla Res Publica, in Studia e Doc. Hist. et Juris, 1944, que opõe o sistema real com um chefe e seu comitatus ao sistema republicano de organização, no qual o direito é que domina o magistrado, o poder é organizado pela lei, muito embora afirme a continuidade exterior do sistema etrusco-romano. Aliás, convém lembrar a velha máxima: "nemo repente fit summus". 
Arangio Ruiz afirma ${ }^{3}$, também sob outro aspecto crítico, que a República é o produto de lenta transformação.

A expulsão dos Etruscos, vencidos na guerra de Cumas, se deu entre os anos 510 a 500 A.C., em proveito das grandes famílias latinas e sabinas. São as gentes que se revoltam contra os Etruscos, poderio que para elas tinha sido nefasto.

A vitória sôbre êles não foi fácil. Após a expulsão de Tarquínio, o rei etrusco, Porsena ${ }^{4}$, invade o campo romano e assedia a cidade, contando com a ajuda da plebe.

Mas o regime etrusco cede em proveito da aristocracia, que suprime o regime monárquico e grande parte das instituições tìpicamente etruscas. As que se conservam ficam inferiores às instituições latinas, como os arúspices ${ }^{5}$, que passam a subordinar-se aos pontífices latinos.

Também o poder grego, no sul da Itália, entra em declínio.

Com a tomada de Cápua em 437, funda-se a federação da Campânia, livre dos Gregos e formada pelos Oscos.

A derrota dos Etruscos libertou, por outro lado, os Equos e os Sabinos, a leste e a nordeste de Roma. Embora ocupados ao norte, contra os Gauleses, os Etruscos deti-

3. Cf. Historia del Diritto Romano, 1952, Introduzione. Outros: autores, como DE MARTino e MAZzarino opinam que houve uma revolução e depois elaboração progressiva, com muita instabilidade, do nôvo regime inaugurado. DE Francisci e GUARINo não particularizam o episódio revolucionário, ao versar o assunto em seus livros, lembrando a reforma militar e a lenta progressão do poder do rei ao magistrado. Dividem-se aí os autores sôbre a maneira, com que se deu essa solução, se apareceu o dictator, depois substituído pelos cônsules; se aquêle era assistido por um magister equitum; se um praetor substituíu o rex; se o colegiado começou com os magistri - equitum et populi... "Tot capita tot sententiae!"

4. Desta época, o episódio de Múcio Scaevola, cuja "clades dextrae manus" é interpretada como ordálio.

5. Haruspex ou Aruspex - Adivinhador, que observa as entranhas da vítima, para adivinhar. 
nham algumas cidades poderosas na região, como a dos Veienses.

Roma está, nesse tempo, muito enfraquecida. Para enfrentar a crise política, firma tratado político e comercial com Cartago, em 509 e tenta assim fazer respeitar seus antigos direitos sôbre o Latium.

Os Cartagineses se absteriam de causar danos, prejuízo e confusão às cidades latinas.

Roma, entretanto, vai à guerra contra seus vizinhos, os Sabinos, contra os Oscos, contra os Latinos, guerras que terminam de 493 a 484, em proveito de Roma, integrando os vencidos a Federaçäo Latina. Outra guerra contra os Volcos e os Equos trazem vitória a Roma, que conta com a ajuda dos Sabinos.

A tomada de Veios, o último baluarte etrusco importante, acarreta o fim da dominação etrusca na região.

Roma, em seguida, é tomada e semi-destruída pelos Gauleses, mais ou menos em 390.

A queda do império etrusco, cujo poderio, ao norte, continha os Gauleses, deixa Roma em perigo até 360. Novas conquistas porém das armas romanas asseguram a federação incipiente.

O regime, que se estabelece em Roma, é aristocrático, tendo o poder total passado às gentes, quais os Quinctii e os Claelii, latinos e os Claudii e Valerii, sabinos.

Os patrícios organizam, em proveito próprio, o poder dirado aos reis e lutam contra qualquer tentativa de reconstituição do poder pessoal.

É esta a luta que exprime a profunda mudança, que se operou na civitas, após a queda da Monarquia.

Pensam alguns que quase nada tenha sido modificado e sòmente em lugar do rei, magistrado único e permanente, apareçam os pretores, mais tarde, cônsules, magistrados anuais e colegiais, em suma, coisas iguais ou muito parecidas. 
Muito ao contrário, a transformação foi profunda.

O novo regime Res populica, Res publica, é a coisa do povo, populus, como conjunto da população romana, e não povo no sentido social, que corresponde à plebè.

Essa noção de Res populica se opõe a Regnum, propriedade do rei, significando que, desde então, o povo é chamado a desempenhar o papel que o rex desempenhava.

$\mathrm{O}$ poder, a potestas, que pertencia outrora ao rei, agora pertence ao populus.

$\mathrm{Na}$ mítica romana, essa revolução conceitual conduziu à liberdade, porque a libertas, no dizer de Títo Lívio e UlPiano, é a potestas sôbre si mesmo ${ }^{6}$.

Potestas, atributo e condição da soberania, é poder e propriedade do populus, agora detentor dessa soberania, res populica. Na monarquia o povo se acha excluído da soberania, daquilo que é propriedade do rei, mesmo agindo num comício curiato ${ }^{7}$.

É o populus, com a revolução de 510, a fonte do poder político, tendo-se operado pois radical transformação.

Mas só após um longo período de instabilidade, que corre de 500 a 367, durante o qual os patricios pretendem exercer sòzinhos o poder, excluindo os plebeus, é que lentamente se criam as formas jurídicas adotadas pelo regime.

A nova organização reduz a autonomia das gentes, a favor de sua integração na res publica e em proveito do poder político da civitas.

Mas, assim mesmo, o poder patricial, que continua enfeixado pelas gentes, acarreta perturbações interiores, com o levantamento da plebe contra os patrícios, dez anos após a queda da monarquia.

6. Materialmente isto não é exato.

7. Cf. WeSENBERG, Zur Frage der Kontimutät Zwischen Königlichergewalt und Beamtengewalt im Rom, in Zeitschrift der Savigny. forschung, 1953. 
- Quais as causas dessa sublevação? - a presença de numerosos ádvenas em Roma, já integrados na plebe e que lutavam, com outros párias, pelo reconhecimento de seus direitos?

- A melhor explicação é que tôda derrubada de um poder monárquico, em proveito de aristocratas, tende a piorar a situação dos não-aristocratas, com a conseqüente humilhação popular.

Integrada no sistema industrial e comercial etrusco, a plebe, em Roma, uma vez privada do apoio político dos. Tarquínios e, por tal, com sua atividade econômica abalada, oferecia aspecto muito diverso da população plebéia agrária.

Assim, é interessante lembrar que o movimento é exclusivamente urbano; que o fim dessas revoltas é a reforma do sistema de empréstimos em dinheiro, altamente ruinoso para os devedores ${ }^{8}$.

$\mathrm{Na}$ agricultura dessa época, empréstimos em dinheiro não tinham aplicação, mas para a plebe, essencialmente artesanal e comerciante, é de suma importância. A participação nas terras conquistadas, exigência da plebe, também se entende como necessidade de volta à terra, uma vez que a situação urbana é insustentável. Daí a luta contra as gentes, pelo direito de cercar e fechar as próprias e pequenas propriedades agrícolas.

A grande arma dos plebeus é a ameaça de separação, ameaça grave politicamente e não sob o aspecto rigorosamente econômico, porque, como se sabe, a organização das gentes não depende da colaboração econômica dos plebeus.

A secessão da plebe é arma decisiva, porque a cidadela, o pomerium ${ }^{9}$, nas mãos dos patrícios, não resistiria

8. Cf. TIBILETTI, Ricerche di storia agraria romana, os dois primeiros artigos da série escrita no Athenaeum, 1948 e 1949.

9. É o espaço de terra junto aos muros da cidade, por dentro e por fora, logo espaço da cidade de intra muros e suas imediações. extra muros. 
muito tempo e os plebeus separariam a cidade de seus territórios, fundando um poder político urbano oposto ao Latium.

Ora, os patrícios não podem aceitar isto.

A plebe, depois da primeira secessão, é coletividade organizada, com assembléia e magistrados próprios.

Vários tratados, concluídos por intermédio dos Tribunos, regulam as relações entre patricios e plebeus. $O$ plebiscito Canuléio e as leis Liciniae Sextiae têm êsse caráter de tratado.

Na luta entre a plebe e o patriciado, os patrícios cedem sempre e os plebeus, aos poucos, econômica e politicamente tomam seu lugar normal na Cidade.

As conquistas plebéias, quais o Tribunato em 491, os Concilia em 471, a lei Canuléia em 465, concedendo aos plebeus o connubium, direito de casamento com os patrícios e, em 449, a promulgação da Lei das XII Tábuas, consolidam uma constituição política patrício-plebéia e criam verdadeiro código de direito privado. Assistimos assim à organização de uma sociedade com dois polos, em que à plebe cabe um poder autônomo, mas com um direito privado comum aos dois grupos.

- Mas como devemos entender essa constituição patrício-plebéia?

Os poderes, que se enfeixavam nas mãos do rex e dos sacerdotes, distribuem-se por inúmeros magistrados dos quais não nos cabe falar no presente. Um ou outro reparo e correlação ou diversidade do que antes se disse, entretanto se fazem necessários.

Os cônsules têm todos os poderes atribuídos ao rei e ainda o auspicium, mas os outros poderes religiosos lhes são retirados e confiados ao rex sacrorum, laicizando-se pois os poderes civis. Não podem também administrar ou distribuir o ager publicus, que é propriedade do povo.

Comandando o exército em campanha, possuem a plenitude do jus vitae necisque e, por isto, se distingue o imperium domi, em Roma, sendo o cônsul precedido pelos 
litores, sem o machado entre os feixes, e o imperium militare, quando os litores levam a machadinha contornada pelos fasces.

Depois da Lei das XII Tábuas, quer por um desenvolvimento talvez espontâneo, quer por uma lei, que assim tenha decidido, os comícios centuriatos têm poder deliberativo ${ }^{10}$.

Reune-se o povo para dar parecer e consentimento à guerra, com a lex de bello indicendo que existe, pelo menos, desde 427. Esta primeira forma de direito de voto se estende logo a tudo o que tinha caráter político, passando assim a ser submetido aos comícios centuriatos os tratados de paz, as alianças e concessão do direito de cidadania, a fundação de colônias, a alienação do ager publicus e a organização das magistraturas e do sacerdócio. Os comícios elegem os cônsules, a partir dos fins do $\mathrm{V}$ século e funcionam como grande juri criminal, a que se submete a provocatio contra os julgamentos dos cônsules e têm ainda o poder legislativo, votando as leis propostas pelos mesmos cônsules.

10. De Franciscr, in Studi in onore di V. Arangio Ruiz, 1, 1953, adota a tese da origem militar e faz os comícios centuriatos remontarem ao século $\mathrm{V}$, antes da Lei das XII Tábuas. Teriam tido assim, antes de 450, um poder político que as XII Tábuas aumentaram. A divisão do povo em classes e em centúrias é a base da organização militar. Cada cidadão se provê por si mesmo de armas, conforme a classe a que pertence. Reune-se em março, no campo de Marte, todo o exército dividido em centúrias. A transformação do exército centuriato em comício centuriato se efetuou, de 475 a 430 . 亡 admissível que, antes da Lei das XII Tábuas, tais comícios se reunissem, por ocasião de reunir-se o exército, a fim de receber as comunicações dos magistrados. Nessa altura, não se descobre neles qualquer poder deliberativo. Há variadas opiniões sôbre o assunto, inclusive in Mél. de Visscher, I, 1949, a de Cavaignac que faz confrontos interessantes sôbre a data da transformação verificada nos comícios e a numismática. ROSENBERG, Untersuchung zur Römischen Zenturienverfassung, 1911, e SchöNBaUer, Die Centurien reform. Studi Albertário I, 1953, estudam interessantemente a questão. 
Essa organização tira às gentes grande parte do antigo poder, reduzindo-as a agrupamentos privados, com os próprios clientes procurando unir-se diretamente à civitas muito mais do que a uma gens.

A Lei das XII Tábuas prevê que o proletário encontrará apoio, junto a qualquer cidadão e não mais forçosamente junto de um patrono.

Exclui-se o sistema de formação do exército, que continua organizado pelas gentes e comandado por patres.

Mas, ao mesmo tempo, os patrícios conservam privilégios importantes, porque os censores, os cônsules, o ditador, os questores, devem todos ser patrícios; igualmente o Senado se compõe ùnicamente dêles. Os comícios centuriatos compreendem certamente patrícios e plebeus, mas a organização é tôda a favor dos patrícios, pois a ordem da votação obedece à riqueza de bens imóveis.

As gentes detêm o solo; os plebeus têm, em geral, meio. hectare de terra que os coloca na quinta classe de votantes.

Os plebeus procuram organizar-se em grupo político. autônomo, para contrapor-se ao sistema patrício.

As instituições tìpicamente plebéias são os edis, os concilia plebis e os tribunos.

Por volta de 493, quando a plebe se retirou para o monte Aventino, após um acôrdo entre os patricios e os plebeus, restabeleceu-se a unidade.

Tratava-se de verdadeiro tratado, de um foedus, que não concede direitos pròpriamente aos plebeus, mas que lhes atribui defensores, perante a civistas e os magistrados; os Tribuni Plebis. Os tribunos não são em rigor magistrados, pois não têm soberania positiva, não possuem imperium, nem auspicium, não podem convocar o senado nem os comícios. Entretanto, uma grande soberania negativa lhes é atribuída pelo direito do veto. O tribuno pode opor-se a tôda e qualquer decisão, que tenha como prejudicial a plebe, porque seu papel essencial é o auxilium plebis. Organiza-se pois, legal e polìticamente, a oposição. 
A origem do instituto dos tribunos é obscura. Não se conhece com exatidão a data da sua criação nem o seu número.

A tradição acolhe que fôssem dois em 491, quatro em 471 e dez em 457. Mas nem o modo de sua escolha sabemos ao certo.

O que sabemos claramente é que o tribuno é sacrosanctus, isto é, "posto à parte com sacralidade". Tal caráter lhe advém, porque a instituição dos tribunos se deu por uma lex sacrata, lei que o povo jura respeitar sob pena de sacralidade e porque o tribuno é investido, com solenidade e palavras mágicas, caerimonae, que nele criam um tabu poderoso. Sua casa, assim, é sagrada e lugar de asilo e sagrados sua pessoa e seus vestidos. Quem o atacar ou o ameaçar ou mesmo o interromper, quando fala, torna-se sacer.

Tal prerrogativa pode êle estender a quem quiser; com o jus auxilii ${ }^{11 .}$

Ao jus auxilii juntou-se o veto, veto mais poderoso do que o de qualquer outro magistrado. Não pode anular mas pode suspender e paralisar as ordens dos cônsules e do senado, as propostas de lei, as eleições, o voto dos comícios, em resumo, todos os atos públicos. Tem pois o tribuno poder de paralisar inteiramente o Estado, impedindo-o, já de tomar decisões, já de aplicar as decisões tomadas.

Com o veto pode intervir nos negócios militares, opondo-se ao recrutamento de tropas, impedir que um general vencedor retorne a Roma, investigar sôbre atos de chefes militares, com respeito aos plebeus, que estão sob suas ordens. $O$ veto pode ser da iniciativa do tribuno ou de um cidadão que o pede com a appellatio.

Dando-se a provocatio ad populum, o tribuno pode mandar prender qualquer magistrado, ainda o cônsul e fazê-lo ser condenado à morte pelo populus.

11. Obra fundamental sôbre o assunto dos tribunos e profundamente atual ainda é a de Niccolini, Il Tribunato della Plebe, 1952. 
— Onde a limitação dêsse imenso poder? - No fato de que o tribuno só pode exercê-lo em Roma e a uma milha ao derredor.

Daí o que dissemos - que a plebe é um elemento urbano e que no campo há poucos plebeus. Até os pequenos lotes de terra, que tivessem recebido, deviam situar-se muito perto de Roma. O tribuno não tem poder no campo, porque aí é o feudo das gentes.

Os edis, escolhidos dentre chefes plebeus do período real, superintendem aos espetáculos. Cuidam da organização das grandes festas e jogos de setembro, em honra de Júpiter.

Trata-se de encargo oneroso, o que vem demonstrar que os plebeus são ricos. Por ocasião dêsses jogos, os edis vestidos de insígnias reais, sentam-se na sede curul reservada aos mais altos magistrados. Da mesma forma que o rex sacrorum, o edil plebeu era sucessor dos reis, sob alguns aspectos.

A plebe reune-se ainda em assembléias independentes, são os concilia plebis, para tomar decisões obrigatórias para todos os plebeus e que são verdadeiras leis, os piebiscita, plebiscitos. Os plebiscitos já obrigam os patrícios, desde 287. A plebe é, pois, um corpo político completo, um contrapêso do corpo político patrício. Não é isto fato anormal ou produto de uma revolta, mas expressão da realidade social e econômica, porque a civitas Romana se compõe dêsses dois elemeritos heterogêneos, aos quais a revolução de 510 restituíu a liberdade, tendo-se ambos organizado, de maneira complementar e encontrando-se nos comícios centuriatos, numa tentativa de integral fusão.

A Lei das XII Tábuas é o máximo instituto a definir a transformação jurídica republicana.

Costumam os historiadores apresentar esta lei como resultado principal do conflito entre plebeus e patrícios ${ }^{12}$.

12. Muitas controvérsias se abrem a respeito das XII Tábuas, Bonfante, no $20^{\circ}$ volume de sua História do Direito Romano, oferece magnífico estudo de conjunto e adota a posição tradicional sôbre a 
Queixavam-se os plebeus de não ter direitos e de ignorar as regras jurídicas aplicadas pelos magistrados, que podiam, portanto, agir de maneira arbitrária. Em 462 um tribuno da plebe teria proposto nomear-se uma comissão, para redigir código de leis especiais para a plebe $\mathrm{e}$ que fôssem reconhecidas pelos patrícios. O Senado decidiu-se por um código comum.

Para isto teria sido nomeada, em 455, uma comissão de três membros encarregados de investigar na Grécia ou nas cidades gregas da Itália, aproveitando sobretudo as leis de Sólon. Em 451, uma nova comissão de dez membros, exclusivamente patrícios, foi nomeada pelos comícios centuriatos, os decemviri legibus scribendis, que, encarregados da redação do código, detiveram todos os poderes, suprimindo-se temporàriamente os magistrados patrícios e os tribunos.

Essa comissão apresentou dez tábuas de leis, que foram votadas pelos comícios centuriatos. Depois, nomeada outra comissão de decênviros patrícios e plebeus, para completar a obra, redigiram duas tábuas complementares e pretenderam exercer um poder pessoal.

Revolta popular ou militar teria derrubado os decênviros e restabelecido a Respublica. Em 449, as duas últimas tábuas foram votadas pelos comícios. A Lei das XII Tábuas, afixada no Forum, foi destruída na tomada de Roma pelos Gauleses ${ }^{13}$. Reconstituídas as tábuas, foram de novo afixadas.

Essa bela e lendária história é vivamente criticada por historiadores modernos, que querem ver, nos textos

matéria. Atualmente, quase todos os estudiosos admitem a autenticidade da Lei das XII Tábuas e a datam do V século. A sua influência deve ser sobretudo considerada como elemento de laicização e objetivação do Direito. Cf. WESTRUP in Sources an Methods, I, 1950, Introduction to early Roman Law.

13. Em 391 os Celtas cruzaram os Apeninos e a Etrúria e em 18 de julho de 390 , a pouca distância de Roma, vencedores em Allia, ficaram senhores em seguida da cidade. 
fragmentários das XII Tábuas, adágios jurídicos do II século.

Tal opinião não pode prevalecer. Há em tudo isto fatos que temos de aceitar como exatos e que são:

1 - a existência de uma lei comum a patrícios e plebeus, em meados do $\mathrm{V}$ século;

2 - a existência dos decênviros;

3 - a validade, como textos dessa lei, de fragmentos que nos chegaram como tais.

Ao contrário, consideram-se como duvidosos:

1 - a viagem à Magna Grécia;

2 - o voto da lei pelos comícios;

3 - os pormenores pitorescos e políticos da história.

Conhecemos muito mal o conteúdo da Lei das XII Tábuas, porque não nos foi transmitida integralmente. $O$ que sôbre isto conhecemos é através de citações esparsas que dela fizeram juristas, advogados e gramáticos. Vê-se, com clareza, que essas leis estâo exaradas em breves sentenças, que visam a regular certos pontos do direito, mas não se trata de um código completo. Não vem ao caso repetir, nesta altura, o conteúdo das Tábuas.

Pela Lei das XII Tábuas, o direito, no seu conjunto, continua bastante primitivo, consagrando a sanção bárbara da sacralidade, a magia, com grandes desigualdades em suas disposições, onde certos textos são muito modernos e isto não nos deve surpreender, pois é assim em quase tôdas as legislações antigas e, por outro lado, apresenta-se como obra muito incompleta.

A Lei das XII Tábuas levanta certo número de problemas relativos a suas características e a seu lugar na sociedade romana.

O problema da influência grega, tão debatido, foge ao âmbito desta exposição.

Ao contrário do que se pensa, a Lei das XII Tábuas não tem por fim nivelar as duas ordens romanas dos 
patrícios e plebeus, pois não traz nenhuma medida para essa igualação ${ }^{14}$ nem é uma codificação pura e simples do direito civil então em vigor, nem sequer visa a transformar um direito costumeiro em direito escrito. Institui simplesmente o jus civile, estabelece os elementos e dados essenciais das ações da lei, que substitui às antigas ações religiosas e elabora medidas de transmissão civil da propriedade, em oposição às medidas religiosas. Nisto consiste seu caráter principal, isto é, a Lei das XII Tábuas laiciza o direito.

Outra característica, que não se pode esquecer, é sua estrutura fragmentária, com grandes lacunas. Não se admite que essas lacunas sejam simples esquecimento; correspondem, pelo contrário, a objetivo visado, isto é, a Lei das XII Tábuas é lei de complemento, a saber, não procura ser uma codificação global de todo o direito, antes, em face do direito existente, mores majorum e leges regiae, estabelece regras para problemas novos e atribui ao direito uma orientação independente.

Representam ainda as XII Tábuas uma lei comum aos patrícios e plebeus.

Não se pode conceber que os plebeus não tivessem antes algum sistema jurídico. Se podiam comerciar, durante o período etrusco, se possuíram instituições públicas e religiosas, tiveram também um direito.

Entretanto, êsse direito se enfraquece ou desaparece talvez parcialmente, por ocasião da mudança do regime e sobretudo porque era direito próprio e interno à plebe.

Havia antes dois sistemas jurídicos fechados, o sistema patrício e o plebeu. O primeiro alcançou preeminência, a partir da República; impunha-se pois estabelecer um direito comum, que fôsse o ponto de encontro entre os dois sistemas. A Lei das XII Tábuas corresponde a isto. Seu conteúdo versa todos aquêles pontos, sobretudo os mais difíceis para um reencontro entre patrícios e plebeus, -

14. MagdelaIN, in Mél. de Visscher IV, Auctoritas Rerum. 
como a afixação de regras de julgar para o magistrado patrício; - o desenrolar do processo entre plebeu e patrício; - os delitos cometidos por magistrados patrícios e seu modo de punição. Nisso se situavam os principais problemas.

Nem esqueceu a Lei das XII Tábuas os modos de contrato entre plebeus e patrícios, nem o contrato de empréstimo em dinheiro, que pesava duramente sôbre os plebeus e adotou formas como a mancipatio e a sponsio, que talvez fôssem proibidas anteriormente a uma dessas classes.

É ainda a característica de direito comum que explica, nas XII Tábuas, o grande número de disposições relativas à propriedade de raiz, ao direito de vizinhança e às servidões.

Tal acontece não porque a sociedade romana fôsse exclusivamente agrária, porque se assim fôsse, a lei não regularia sobretudo as propriedades fechadas, quando o grande e conhecido sistema é a propriedade aberta para a pastagem.

Ora, os plebeus tinham pedido e obtido terras; querem ir para o campo, mudam de ofício e têm, desde então, pequenas propriedades fechadas para cultura. Era forçoso então que um direito comum agrário estabelecesse as relações entre plebeus e patrícios, nesse sector relativamente novo. Dessas considerações decorrem a importância e o papel da Lei das XII Tábuas.

A nota essencial das transformações institucionais, no curso do $\mathrm{V}$ século, decorrente da constituição patrícioplebéia e da Lei das XII Tábuas, é a laicização do direito e da civitas. Não quer isto dizer que a religião fôsse excluída da civitas ou que se adotasse uma política antireligiosa, mas que apenas os dois campos se separaram, que se procedeu a um rompimento na confusão, que se sabe ter existido, entre as áreas religiosa e jurídica. 
Os Romanos são o primeiro povo da antigüidade a laicizar o direito ${ }^{15}$, assegurando-lhe assim possibilidade de desenvolvimento e de racionalidade. A laicização atinge não só as magistraturas, mas o próprio direito. O que é mais notável é que não foi isto o fruto de algumas decisões racionalmente concebidas, mas duma orientação geral da mentalidade, constituindo evolução e progresso.

Com a República tirou-se aos magistrados, sucessores dos reis, o poder religioso, para que não houvesse possibilidade de restauração do poder pessoal. Ao rex sacrorum, detentor do poder religioso, é atribuído domínio muito limitado; não pode pretender magistratura pública, deve ausentar-se das cúrias, depois de cumpridos os ritos. Os magistrados tomam os auspicia, mas da forma como qualquer cidadão o podia fazer, auspicia, que não têm, de modo algum, valor equivalente ao augurium. A organização religiosa, de agora em diante, se apresenta sem qualquer fôrça no domínio político, que se desenvolve como puramente humano, sem referência ao divino.

Desaparece assim o caráter teocêntrico que a civitas possuía primitivamente. Conservam-se, é verdade, certos ritos religiosos públicos, como para o foedus, mas que vão perdendo sua fôrça.

Para entender-se a laicização do direito a primeira idéia é que, depois da Lei das XII Tábuas, o direito repousa sôbre a lei, sôbre as palavras da lei; é um direito objetivo.

A validade e eficácia do ato jurídico, que outrora provinham dos ritos, da magia, dos juramentos, agora decorrem da lei; o jurídico é válido porque a lei lhe dá validade.

A fórmula, ita jus esto, que fecha muitos textos da Lei das XII Tábuas, indica que o jus existe, porque a lex o diz e que só existe de conformidade com a mesma lei.

15. Cf. PAOLI, Jus Papirianum in Revue Historique du Droit Français et Etranger, v. 1947, estudo sôbre a laicização, sem especialidade sôbre as XII Tábuas. 
Tira-se assim a importância ao fas e ao jurare, sôbre os quais se fundava o direito, jus jurare, - o que significa modificação evidente, para um sentido leigo, de todos os atos jurídicos tradicionais. Esse espírito da Lei das XII Tábuas diminui de importância os atos dos comícios curiatos e assim, o testamento e a adrogatio não repousam mais sôbre a auctoritas dos comícios curiatos, mas sôbre a fôrça da lei, preexistente ao ato. Da mesma forma, isto vem tirar aos atos jurídicos sua habitual sanção religiosa, a sacralidade.

Qualquer um se tornava automàticamente sacer, quando tivesse traído um juramento. Agora já não é mais sacer, pois desobedece a um ato jurídico fundado só sôbre a lei e a própria sacralidade só pode aparecer como sanção excepcional e especialmente prevista pela mesma lei.

Impõe-se pois organizar sanções civis e jurídicas e parece que então aí surgiram alguns embaraços.

Com efeito, por exemplo, subsiste a sacralidade como conclusão do processo de execução num julgamento, porém, êste último não sendo mais religioso não havia motivo para tal, o que faz o sistema cair em desuso. No processo, não se pode, no sistema laicizado, entregar aos áugures o poder de decidir qual é a afirmação justa. Estabelece então a lei o processo do sacramentum leigo e o processo independente de execução das sentenças. Destarte, a interpretação e a conservação do direito deixam progressivamente de pertencer aos pontífices.

Pode-se assinalar entre 449 e 339, portanto após a Lei das XII Tábuas, a codificação do Mos Ritusque Sacrorum, que se faz após o Jus Civile e à sua semelhança, reunindo os costumes do direito sagrado numa lex Papiria ${ }^{16}$, que talvez se identifique com o jus Papirianum.

Diverso e diferente era o jus pontificium, pois era secreto. O Mos Ritusque Sacrorum devia compreender a relação e as regras de consagração de bens aos deuses que,

16. Cf. PAoLI, artigo citado. 
uma vez regulamentadas, foram submetidas ao beneplácito da plebe, ao jussus plebis, através de compilação que integrava uma lex tribunicia. Tratava-se de novo ato de laicização, acentuando-se a separação entre o jus civile e o jus sacrorum, pela intervenção da plebe nesse último.

A celeuma em tôrno do problema resolvido pela lei Canuléia mostra também a tendência à laicização, admitindo-se os plebeus aos ritos patrícios do casamento. É também desta época em diante que os escravos poderão ser admitidos entre os cidadãos, pela alforria.

Mas caracteres religiosos também subsistem; por exemplo, com a cidadania que é, ao mesmo tempo, política e religiosa. Tal laço religioso e político aparece claramente por ocasião do lustrum que encerra o recenseamento. $O$ lustrum ${ }^{17}$, liga os cidadãos uns aos outros e os deuses são fiadores da ordem assim fixada na Cidade. Quando os patres recusavam aos plebeus o acesso ao consulado, assim procediam porque os deuses não poderiam suportar uma tal subversão.

Não obstante essas observações, a laicização se manifesta em todo conjunto do direjto.

A partir da Lei das XII Tábuas, magistratura e jurisprudência estão submetidas à soberania da lei e não mais a imperativos religiosos. $O$ mesmo se observa com respeito ao direito penal, que sob tais influências muda de caráter.

Em muitos casos a Lei das XII Tábuas é obrigada a manter disposições já existentes, como para o roubo flagrante e para a feitiçaria. Mas nesses casos, a lei decide que não se pode mais executar um homo sacer, sem um julgamento prévio. A pena é, além disto, desligada do delito em si e ligada ao julgamento; a execução capital, que tende a substituir o linchamento, é decidida por ato

17 Tiтo Lívio I, 44: "censu perfecto edixit ut omnes cives Romani in campo prima luce adessent. Ibi exercitum omnem suove taurinibus Iustravit, idque conditum Iustrum appellavit"

Sacrifício expiatório, cerimônia purificadora feita pelos censores, de cinco em cinco anos. Havia, na ocasião, revista do exército. 
público e a jurisdição criminal é decorrência do jus. Por outro lado, a Lei das XII Tábuas começa a estabelecer sanção a atos até então deixados sem pena pública, o que vale dizer enfim que se começa a considerar o elemento subjetivo do delito, a vontade, de maneira mais sistemática ${ }^{18}$. É preciso ter agido sciens, ao matar ou consilio, ao praticar o roubo, para ser punido; para o delito se faz mister a intenção de prejudicar. Em tudo isto se vê a laicização do direito penal, que não repousa mais sôbre o conceito de delito contra os deuses e de sanção religiosa automática, mas sôbre a noção do delito contra o homem, levando-se em conta indivíduos e interêsses em choque.

Roma entretanto permanece uma civitas. Consegue conquistar a Itália, destruir Cartago, apoderar-se da Grécia e da Macedônia, da Ásia Menor, da Espanha, mas continua, embora centro de seu grande império, uma civitas. De fato, três continuam a ser os órgãos de direção: Magistrados, Senado e Comícios, que tinham bastado a Roma, quando só possuia o Lácio. Ésses mesmos órgãos de administração da cidade tornaram-se órgãos de direção política do seu império.

Seus magistrados têm todos a potestas, que é o poder de agir com fôrça em nome da Respublica. Na potestas se inclui o poder do magistrado de dar ordens, no exercício de sua função e para assegurar êste mesmo exercício. Representa o magistrado, com a potestas, a própria Respublica, para concluir um tratado com um particular, no caso do arrendamento dos impostos, de compras e vendas públicas, nos atos administrativos do domínio público. Porém, o magistrado representa ainda a Respublica em suas relações com os deuses, para concluir votos, devoções, consagrações e dedicações e em sua relação com as po-

18. Cf De Robertis, La Variazione della Pena in Diritto Romano, 1949/1951. Livro completo sôbre a análise da pena, seu papel e sua evolução e que vem acrescentar minúcias e desenvolver o artigo do mesmo autor, in Studi Siro Solazzi, 1949, La funzione della pena nell diritto romano. 
tências estrangeiras, para praticar atos preparatórios de tratados, sponsio praevia.

Caracteriza-se a potestas por dois elementos a intercessio ${ }^{19}$, pela qual o magistrado pode opor-se ao ato de um colega e pela faculdade de nomear funcionário, quer sucessores, quer colegas e ainda auxiliares subalternos, a quem podiam delegar a potestas.

Entretanto, o imperium é indelegável. O subalterno nomeado recebe uma função específica, retirada do próprio magistrado.

Certos magistrados possuem ainda o auspicium, isto é, o direito de invocar a aprovação ou a desaprovação dos deuses, sobretudo de Júpiter, concernente a um ato público político ou jurídico, pela consulta a certos sinais, como o vôo dos pássaros, a incidência dos relâmpagos, os gritos dos quadrúpedes, porém os magistrados, quando o fazem, agem em nome da Respublica. Só excepcionalmente um magistrado, que não tem o imperium, poderá tomar auspicia, como o Questor e os Edis.

Os auspícios são obrigatórios na nomeação de magistrados, na convocação dos comícios e na partida das tropas para a guerra. Outros magistrados possuem o imperium, o mais alto poder público, compreendendo o imperium militare e a juris dictio, em oposição, de uma parte ao poder de interdição, intercessio e por outra, ao poder inferior de usar da potestas, no sentido estrito. Os magistrados possuidores do imperium são o ditador, os cônsules, o pretor.

Distinguem-se no imperium, o imperium domi e o imperium militiae.

O imperium domi se exerce na Urbs e a uma milha ao redor. Êste imperium compreende não só atos civis, mas também atos militares, como a formação e o recruta-

19. Cf. Digesto, XVI, 1, 8, 1- "Alienam obligationem recipere", ut Papinianus. 
mento do exército. O imperium militiae se exerce fora dos limites da Urbe e compreende também atos militares e civis como por exemplo, a jurisdição, a administração dos territórios. Assim, o mesmo magistrado possui um e outro imperium, conforme esteja na cidade ou fora dela.

Esta dualidade é a regra para os magistrados.

O conteúdo imperium ${ }^{20}$ varia segundo o caso. Por exemplo, o imperium domi proíbe ao magistrado as condenações à morte, enquanto que o imperium militiae as autoriza. Os magistrados da plebe não possuem nenhum poder, ao transpor os limites de Roma.

Outros magistrados não possuem mais que o imperium militiae; os pretores provinciais e os questores provinciais não possuem nenhum poder em Roma.

O imperium domi compreende, como caráter essencial, o direito de coerção: o do magistrado que emite uma ordem e faz justiça contra um cidadão, que recusa obedecer.

O magistrado, verificando a infração, pode infligir a pena prevista. A coerção pode ser relativa quer à pessoa, quer aos bens. Para a pessoa livre só pode haver pena de morte, com a provocatio ad populum; há penas corporais, flagelação e prisão. Para o patrimônio pode haver a confiscação dos bens, a transferência do patrimônio para outra pessoa, a tomada de um penhor, pignoris capio. $\mathrm{O}$ mais freqüente é serem estas últimas aplicadas por um pretor. Enfim, há penas que podem ser impostas pelos magistrados que só possuem a potestas e não o imperium.

20. Para os Romanos havia diferença entre imperium e jurisdictio. Esta era conhecimento e julgamento das causas, enquanto a execução da sentença era ato de imperium. O imperium, conforme o conhecido trecho de UlPIANo era merum e mixtum. "Merum est imperium habere gladii potestatem ad animadvertendum facinorosos homines, quod etiam potestas appellatur. Mixtum est imperium, cui etiam jurisdicito inest, quod in danda bonorum possessione consistit, jurisdictio est etiam judicis dandi licentia". Dig. II, 1, 1, 2. 
A juris dictio é também um elemento do imperium. Todos os magistrados superiores a possuem. Mas é exercida sobretudo pelo pretor e pelos edis.

É o poder de dizer o direito.

Em virtude da juris dictio, o magistrado possui um triplo poder, um concernente à jurisdição criminal, cognitio, desde que seja o Estado mesmo que age contra o criminoso. $\mathrm{O}$ segundo diz respeito à jurisdição administrativa, para com o patrimônio do Estado e seus créditos. $O$ terceiro diz respeito à jurisdição civil e processual entre cidadãos romanos.

Distingue-se a juris dictio voluntaria - graciosa - e a juris dictio contentiosa - contenciosa. Esta é exatamente o poder de organizar os processos.

Os litigantes se apresentam diante do magistrado e cumprem os atos de procedimento decorrentes da questão em litígio. $O$ magistrado pode recusar-se a abrir o processo.

A juris dictio não pode ser exercida senão em funçâo ra lei e nos limites da lei.

Ela dá lugar ao processo baseado na lei, judicium legitimum.

- Como eram porém escolhidos os magistrados? Eram nomeados por eleição. A eleição é o critério da magistratura, para o pensamento republicano.

O magistrado não é um magister, mas é um que foi chamado pelos seus iguais para dirigir. E a eleição que distingue, por exemplo, o magistratus do sacerdote ou das funções de autoridade não eletivas chamadas munera.

Para ser eleito, é necessário preencher certas" condições: ser cidadão, ser do sexo masculino, ser patrício para as magistraturas patricias e plebeu para a magistraturas plebéias, ter feito o serviço militar e respondido, durante dez anos, às chamadas anuais do exército, que começa aos 17 anos, portanto, ter 27 anos; ser plenamente cidadão e não civis sine suffragio, não ser indigno, apontado pela 
nota censoria ou atingido pela infamia, por causa de falência.

Não era permitido, em princípio, acumuīar várias magistraturas, mas havia atenuantes; podia-se acumular uma magistratura anual com uma magistratura não permanente, como a ditadura e a censura.

Mas o ofício de rex sacrorum não se acumulava com o de uma magistratura.

É necessário ainda tratar do cursus honorum. Este repousa sôbre dois princípios estabelecidos progressivamente. Por um lado, é proibida a reeleição numa magistratura, por outro, há uma sucessão na ordem das nomeações, obedecidos certos intervalos.

O primeiro princípio foi fixado por um plebiscito por volta de 340 , que decidiu que não se podia ocupar, por duas vêzes, o mesmo cargo, a não ser depois de um intervalo de dez anos. Proibia-se tôda reeleição para a censura, em 275, e para o consulado, em 151. Desde a sua origem, já era proibida a reeleição para o tribunato.

O segundo princípio foi fixado primeiro pelo costume, segundo o qual era necessário começar pelas magistraturas inferiores e alcançar progressivamente as superiores. Depois, a lei Villia em 180, transformou isto em gradação legal.

Outras medidas acrescentaram-se e o cursus honorum ficou assim fixado: tribunato da legião (oficial do exército), vigintivirato (grupo de pequenas magistraturas); iriunviri capitales, decemviri litibus judicandis, magistrado das moedas, questores, edis curues, pretores, cônsules.

Enfim, entre cada magistratura e a seguinte foi estabelecido certo intervalo; dois anos entre pretura e consulado e entre edilidade e pretura.

Não obstante, êste intervalo não é necessário para a sucessão nas magistraturas plebéias. Por conseguinte, em virtude da lei Villia, não se pode ser questor senão aos 
vinte e sete anos, edil curul aos trinta, pretor aos trinta e três e cônsul aos trinta e seis ${ }^{21}$.

Para concorrer à eleição, o candidato deve fazer uma declaração ao magistrado, que preside ao voto, a fim de inscrever-se na lista dos candidatos, é a professio. O magistrado pode aceitar a inscrição ou recusá-la arbitràriamente. A lista, redigida vinte quatro dias antes da votação, é afixada.

Os questores e os edis são eleitos nos comícios tribunícios, tendo como presidente com voto, um cônsul. Os censores, cônsules, pretores, são eleitos pelos comícios centuriatos, sob a presidência de um cônsul.

Em suma, é o cônsul que possui o poder de fazer os magistrados. Uma vez terminada a eleição, o candidato eleito deve obter dois atos confirmatórios: um dos deuses, deve consultar o auspicium, para obter o consentimento da divindade; outro do povo, os comícios curiatos devem sempre votar a lex curiata de imperio, que atribui o imperium requerido.

Sôbre os magistrados da Respublica digamos algo, ao menos pela rama.

Os censores são dois. Em tôdas as decisões devem estar de acôrdo, não havendo intercessio entre ambos nem veto do tribuno contra suas ordens. Nomeados por cinco anos, intervalo entre dois recenceamentos, os censores exercem o cargo durante dezoito meses. Devem desempenhar-se de seu munus, dentro dêsse periodo e seu ministério ativo termina por um grande sacrifício, o Suoveiaurile $^{23}$, que é um sacrifício de purificação das manchas e pecados, com que a comunidade se onerou nos cinco

21. Esse limite da idade influíu na capacidade para os cargos políticos e eletivos em muitas nações modernas. Trinta e seis anos da contagem latina - sexto et tricesimo anno natus - corresponde, na nossa contagem, aos 35 anos feitos.

22. Cf. a nota anterior sôbre o lustrum, cerimônia final do recenseamento. 
anos passados. Êsse ato religioso é o Lustrum, que encerra o recenceamento e estabelece o laço religioso da civitas, na sua integridade. $O$ recenceamento se torna intangível, após o Lustrum.

De início, os censores foram patrícios; a partir de 366, um dêles pode ser plebeu. Não cuidavam só do recenseamento e de repartir os cidadãos em centúrias. Administram ainda o ager publicus, isto é, as terras públicas e a sua distribuição e locação; contratam o arrendamento dos impostos aos publicanos, conseqüentemente dirigem o mecanismo das finanças públicas, uma vez que é por intermédio dêles que entram os principais recursos. Seu encargo preponderante é o cômputo geral dos cidadãos, ef etuado por ocasião da inscrição nas listas do censo. Essa inscrição é que consagra o lugar do homem na comunidade política. Os censores são, pois, encarregados de organizar a cidade, social e politicamente, inscrevendo os indivíduos como livres ou escravos, podendo assim atribuir a liberdade a um escravo, por êsse modo de alforria oficializada. Podem excluir cidadãos do exército como indignos, bem como, do corpo eleitoral; podem mudar de classe um cidadão, rebaixando, por exemplo, um cavaleiro, ao lugar de simples cidadão, e fazendo-o vender o cavalo, por dever de ofício.

Em 312, o plebiscito Ovinius lhes atribui o encargo de fazer a lista do Senado, podendo pois os censores nomear novos senadores e excluir outros.

$O$ recenseamento é a ocasião, na qual um estrangeiro pode ser admitido na civitas e na sua política, após ser apresentado por um ou mais cidadãos. Isto talvez se ligue ao antigo hospitium ${ }^{23}$.

23. Pròpriamente, o direito de hospitalidade é só atribuído ao Romano. Há o hospitium privatum e o publicum. Este último é um tratado de hospitalidade ou amizade entre a civitas Romana e uma outra ou mesmo entre Roma e particulares. O pacto entre particulares é perpétuo e vincula os descendentes e se dá por garantia das relações de hospitalidade entre um cidadão e um hostis ou peregrinus. 
$\mathrm{Na}$ época das inscrições, os censores levantam o regimen morum, isto é escrevem uma espécie de julgamento moral do cidadão. Avaliam as omissões aos deveres políticos e militares, a falta de respeito para com os magistrados, os falsos juramentos, as falências, as condenações infamantes, o excesso de divórcios, a alienação do patrimônio ancestral, os abusos do pátrio poder. Igualmente avaliam os abusos cometidos pelos juízes e magistrados. Quando julgam necessário, expedem a nota censoria.

Quem não se inscrevia junto ao censor, estava incensus, não tinha nenhum direito político e não fazia parte da Cidade, era um Romano decaído, podendo o cônsul vendê-lo ao estrangeiro, reduzindo-o a escravidão. Com tão imensos poderes, os censores, se quisessem, poderiam dominar a República, como o fêz, com efeito, Appius Claudius, em 312.

Aos cônsules o auspicium deve ser transmitido por seus predecessores, como símbolo da continuidade do poder.

Isto provém da monarquia e é essencial que não se interrompa a cadeia consular que deve ser contínua. Sôbre os ombros dos cônsules assenta-se a Respublica; por isto a importância da transmissão do Auspicium.

A partir de 367, a administração da justiça é atribuida a um pretor ${ }^{24}$.

24. O têrmo vem de prae-ire, - ir na frente, comandar, dirigir. Foi inicialmente cargo militar - "qui praeibat exercitui dicebatur praetor, postea magistratus est ad dicendum jus".

O praetor urbanus é o juiz de Roma para os litígios entre os cidadãos; foi criado em 367 A.C. e tem o adjetivo, por residir regularmente na cidade. O praetor peregrinus foi criado em 240. Possuíam - imperium. Há uma série longa de adjetivos, diferenciando os pretores. Havia assim o praetor provinciae, governador das Províncias, os praetores fideicommissarii, os de liberalibus causis etc. Os pretores eram acompanhados de dois litores, lictores, que levavam os fasces, indicando a potestas cum imperio. Nas Províncias eram seis os litores, ao lado do pretor. 
Há nisso, sem dúvida, a vontade dos patrícios de conservar a direção da ordem judiciária. Mas há também o fato de que o recrudescimento de tarefas e sobrecargas consulares e a complicação da administração da justiça exigiam especialização.

$\mathrm{Na}$ realidade, o pretor é um terceiro cônsul, menor em relação aos outros dois, mas possui todos os poderes dos cônsules, salvo a presidência das assembléias do povo.

Muito cedo perde seus poderes militares. Era cargo exclusivamente patrício, no início, mas logo foi aberto aos plebeus.

O pretor preside à justiça. Como êsse encargo fôsse muito pesado foi-lhe dado um auxiliar, o praetor peregrinus, encarregado da justiça entre cidadãos e peregrinos, estrangeiros.

O pretor possui triplo encargo. Em primeiro lugar, fixa no seu edito ${ }^{25}$, que formula, cada ano, ao assumir o cargo, as condições nas quais aceitará sancionar um direito, que lhe é apresentado e contestado.

Nem em todos os casos, pode tomar essa iniciativa.

Está impedido, sempre que uma lei já tenha estabelecido ou sancionado um direito. Mas nas hipóteses onde nada tenha sido previsto, o pretor pode, no seu edito, estabelecer uma forma de ação e por ela pode criar um direito, em benefício daquele que passará a usar dessa condição.

O pretor organiza ainda os processos, seguindo as regras de seu próprio edito. Não julga os processos realmente, limita-se a autorizar a ação, a colocar as pretensões dos adversários em forma processual, a preparar o regulamento do processo e a dar a um juiz o poder de julgá-lo, nos limites formulados por êle mesmo pretor.

25. Edito - de edicere, era uma plataforma, com fôrça constitucional, que o pretor compunha, fixando o seu modo de govêrno e pela qual intimava o povo a conhecer da forma legal da distribuição da justiça. 
Em suma, deve indicar a regra juridica a aplicar-se, mas não tem que se preocupar com fatos precisos, nem com as provas que cada um possa apresentar.

Enfim, o pretor possui um terceiro poder. Seu imperium lhe outorga um comando, em matéria jurídica, a execução.

Tem o poder tanto sôbre os cidadãos, como sôbre os peregrinos; sôbre os habitantes da Itália, como sôbre os provincianos. Ordena e proíbe em matéria jurídica e sôbre as questões que poderiam fazer surgir um processo, através de seus interditos ${ }^{26}$. Pode exigir das partes, por contrato, uma obrigação, é a estipulação pretoriana ${ }^{27}$.

Pode o pretor obrigar as partes e ater-se à inexistência de um ato, mas por sua exclusiva autoridade não pode anulá-lo.

Em tal caso, coloca a situação no estado antes existente e anterior a ter o ato sido praticado, é a restitutio in integrum ${ }^{28}$.

26. Interditos. Ordem de fazer alguma coisa ou de se abster de realizar um determinado ato, dado pelo Pretor ou Governador em virtude de seu imperium. Além do sentido jurídico, há o genérico e comum na língua latina. Cf. ForCelliNI - Lexicon Totius Latinitatis, editio in Germania prima.

27. Stipulationes praetorianae. São promessas orais e solenes que - pretor exige de uma das partes até com fiadores, daí chamar-se também cautiones. Stipulatio deriva-se de stipula, a palha quebrada e cruzada em partes, garantia de uma promessa, como o fio de barba dos antigos.

No direito romano há série grande de stipulationes; assim, a stipulatio judicialis, stipulatio poenae, stipulatio aedilicia. PoMPôNIo, no Dig. 45, 1, 5, 1 define-a: "Stipulatio est verborum conceptio, quibus is qui interrogatus responderit"

28. A restitutio in integrun é o remédio contra situações e sentenças de condenação excessiva ou inferior à pleiteada. $\mathbf{E}$ remédio extraordinário e à falta de outro. É concedida por via de decreto do magistrado, com as palavras: "ratum non habebo, perinde erit quasi id factum non sit". A restitutio é ato de imperium e pode originar nova instância, na qual as pretensões do restitutos poderão basear-se em novos argumentos. Interposta essa instância, temos a actio rescis- 
O pretor tem mais o poder de entregar a uma pessoa todo o patrimônio de uma outra, para forçá-la à obediência, é a missio in possessionem ${ }^{29}$.

Êstes meios de autoridade permitem ao pretor intervir profundamente na vida jurídica. As suas funções desenvolvem-se progressivamente, entre o III e o II século, para ter a plenitude, no I século antes de Cristo.

Vejamos, per summa capita, as fontes do Direito.

Com a República, no período que corre do século $V$ ao século II A.C., começam a separar-se o direito público, o direito privado e o direito sagrado.

$\mathrm{O}$ direito público diz respeito à organização da Respublica, da Civitas e das Províncias, tem caráter social e político.

O direito privado respeita à organização das relações entre os particulares, indivíduos, cidadãos, Latinos ou grupos privados, família, sociedade e tem mais caráter ético e econômico.

O jus sacrum concerne às relações com os deuses. É completamente separado do resto e regulamenta as relações, tanto entre a cidade e os deuses, como entre os cidadãos e os deuses.

Essas distinções se efetuam no III século. O direito anterior ao III século toma, pouco a pouco, o nome de Jus Quiritium; designava então qualificação jurídica do que pertencia aos Quirites. É possível que tenha sido a mais antiga forma para indicar o direito de cidadania romana, em oposição às cidadanias latinas.

Poderia significar também as instituições oriundas dos Sabinos, como concorda um grande número de autores.

soria ou restitutoria ou de judicium rescissorium. Cf. BONFANTE, I, p. 521 da Histoire du Droit Romain, 1928, Paris, traduite par CARRÈrE et FOURNIER.

29. Imissão na posse. $\mathbf{E}$ medida conservatória tomada pelo pretor. A pessoa imitida na posse fica protegida por uma ação in factum ou um interdito. 
Êsse jus Quiritium é formalista, comporta atos, gestos rituais e simbólicos, conforme antigos ritos mágicos, agora Laicizados. Esse formalismo repousa sôbre a idéia de equilíbrio para as relações jurídicas, o qual não pode ser rompido ou restabelecido, senão conforme formas precisas.

E também verbal; a preeminência pertence à palavra e à fórmula. A palavra possuia aliás, um valor mágico, no início. Tôda essa importância se fundamenta na idéia de fides, confiança nos outros cidadãos, boa-fé para com os outros.

E direito também essencialmente costumeiro, onde se dá importância essencial à personalidade nos atos jurídicos, isto é, um ato deve ser feito pela pessoa a quem diz respeito e só por ela, se ela é capaz. Não se pode, de resto, nem adquirir nem obrigar-se, nem agir em juízo por intermediário.

É sistema jurídico realista e objetivo, não visando a organizar direitos, que se possam exercer sôbre tal bem ou em tal circunstâncias, mas a realidade mesma, as pessoas, as coisas, as atividades.

Quando nesse sistema jurídico se fala de jura, não se pensa em direitos subjetivos, porém numa categoria especial de coisas, coisas incorpóreas e assim objetos de certa forma.

O jus Quiritium faz parte de uma categoria mais vasta, que parece nascer no III século, o jus civile. Na origem, - jus civile foi talvez o direito costumeiro interpretado pelos jurisconsultos, os prudentes. No século III, porém engloba todo o direito fundado sôbre a lei. Assim o jus civile constitui um conjunto formado do jus Quiritium, da Lei das XII Tábuas e de sua interpretatio, das leis posteriores votadas pelos comícios e da interpretatio delas.

Em confronto com o jus civile, aparece o jus honorarium fundado sôbre os editos dos magistrados.

Um certo número de diferença entre o jus civile e o jus honorarium se apontam: - O jus honorarium está 
subordinado, em princípio, ao jus civile: existe como auxílio na aplicação do jus civile, completando-o, reformando-o.

Se antagônicos, vence o jus civile teòricamente; na prática, o jus honorarium, mais leve e mais adaptado ganhará sem cessar.

- O jus civile se aplica teòricamente em todo o Império Romano, o jus honorarium ùnicamente onde o magistrado tem competência de agir.

- O jus civile se aplica indefinidamente. O edito pronunciado cada ano não cria senão um direito anual, porém, toma-se o hábito de reproduzir sempre as mesmas regras nos editos sucessivos e, por conseqüência, há uma permanência do jus honorarium.

- O legislador, no jus civile, procede por via imperativa e cria princípios de novo direito. $O$ pretor sòmente dá seu parecer e declara que êle concederá tal meio de procedimento, para sancionar tal ato jurídico desconhecido do jus civile, ou para impedir a execução de tal ato reconhecido pelo jus civile. Assim, o jus honorarium não é obrigatório para o juiz, a não ser com indicação expressa do magistrado e em cada caso.

Desde o comêço da República, parece desenvolver-se em Roma um jus gentium. É difícil saber exatamente a que corresponde. Não deve ser nem criação específica dos Romanos nem uma espécie de direito comum a todos os povos do Mediterrâneo. Talvez os Romanos dêem êsse nome às instituições de povos estrangeiros, as quais reconhecem, aceitam e aplicam, seja por fôrça de tratados, seja por fundamento na fides.

Nas suas relações com os estrangeiros, os Romanos do IV século, por exemplo, não aplicam evidentemente as formas do direito romano. Estas relações repousam sôbre a fides ${ }^{30}$.

30. Correlato ao conceito de fides e à evolução, que sofre, encontramos o mesmo a respeito de auctoritas. Auctoritas do pontífice para certos atos; do pater no casamento da filha; do tutor para o ato do pupilo; do Senado para atos dos comícios e dos magistrados; mais 
São sobretudo relações comerciais. Procura-se então mais a vontade e avaliação do comportamento das partes e leva-se em conta o objetivo do ato e seu conteúdo econômico, mais que a sua forma. Isto acarreta uma certa modificação na noção da fides, acrescentando-lhe a nota do dever de proteção e de fides ser um valor moral, sendo melhor freqüentemente qualificada de bona fides. Nesta perspectiva ela se aplicará a contratos alicerçados sôbre a relação de confiança pessoal dada à boa conduta média, que deve ter um cidadão, como por exemplo, nos contratos de sociedade, de mandato, de depósito. Acentua-se isto depois da criação do pretor peregrino, que é encarregado ùnicamente das relações entre cidadãos e estrangeiros e depois, dêstes entre si. O pretor peregrino, de um lado, sanciona o jus gentium, dantes existente a titulo costumeiro, por outro lado, sistematiza os contratos e procedimentos empregados, com seu edito. Enfim, faz progressivamente entrar êste jus gentium no próprio direito romano, quando o pretor urbano adota instituições à imilação do jus gentium.

Isto se produz muito mais tarde, em fins do II século e I século A.C.

As instituições romanas que daí se derivam levam então nomes, com respeito a seu conteúdo econômico, emptum venditum, locatum conductum, societas, enquanto os antigos atos trazem nome relacionado com o ritual empregado, mancipio, sponsio, adrogatio e outros.

É preciso ainda lembrar que, sôbre êsse conjunto jurídico, a partir do fim do III século, começa a manifestar-se uma certa influência helenística, relacionada com o direito.

tarde, há a auctoritas principis; a auctoritas daquele que é chamado a juízo para garantia de um direito; a auctoritas do mancipante na mancipação; a auctoritas aeterna do titular do direito contra o ladrão e o estrangeiro e até a auctoritas do contrato de auctoramentum, pelo qual se obrigava um gladiador. 
O helenismo conduz à especialização da profissão jurídica e acaba de laicizar o direito. Abranda as formas e faz aplicar novos métodos de interpretação do direito. Até então, a ciência jurídica era aristocrática e autoritária. O mos maiorum bastava como argumento. E o helenismo que introduz o jôgo do raciocínio dialético no direito, constituindo-se como forte e decisiva influência maior, sem dúvida, do que princípio de liberdade ou o individualismo. Essa influência direta helenística se exerceu, na prática, pelas relações comerciais.

Por isto, mais uma vez, se pode fechar estudo desta natureza, com a frase do poeta: "Graecia capta ferum victorem vicit et artes intulit agresti Latio", sem esquecer o complemento de Carducci - "e tutto che al mondo $\dot{e}$ civile, grande, augusto, egli è romano ancora"! 